8. Serbenskaya, O. (2006). Movnyi svit Ivana Franka: Statti, rozdumy, materialy [Language world of Ivan Franko: Articles, thoughts, materials]. Lviv, 372 p. [in Ukrainian].

9. Steger, L.V., \& Kiseleva, V.V. (1987). Ekspressivnost kak linhvostilisticheskaia katehoriia [Expression as a lingvo-stylistic category]. Questions of functional lexicology. Moscow, pp. 50-54. [in Russian].

10. Franko, I. (1976-1986). Zibrannia tvoriv: $u$ $50 t$. [Collected Works: $50 \mathrm{v}$ ]. Kyiv: Science. thought, Vol. 20. [in Ukrainian].

11. Franko, I. (1976-1986). Zibrannia tvoriv: $u$
$50 t$. [Collected Works: $50 \mathrm{v}$ ]. Kyiv: Science thought, Vol. 22. [in Ukrainian].

12. Chabanenko, V. A. (1984). Osnovy movnoii ekspresii [Fundamentals of linguistic expression]. Kyiv: High school,165 p. [in Ukrainian].

13. Chabanenko, V.A. (2002). Stylistyka ekspresyvnykh zasobiv ukraiinskoii movy [Stylistics of expressive means of the Ukrainian language]. Zaporozhia: ZDU, 351 p. [in Ukrainian].

14. Telia, V. N. (Ed.). (1991). Chelovecheskoi factor v iazyke: Iazykovyie mechanizmy ekspressivnosti [The human factor in the language: Language mechanisms of expressiveness]. Moscov: Science, 214 p. [in Russian].

Стаття надійшла до редакції 06.12.2018

УДК 37.015.31:7(091)

DOI:

Неля Сірант, асистент кафедри початкової та дошкільної освіти Львівського національного університету імені Івана Франка

\title{
ПРОБЛЕМИ ЕСТЕТИЧНОГО ВИХОВАННЯ ДІТЕЙ В ІСТОРИЧНІЙ РЕТРОСПЕКТИВІ
}

У статті здійснено спробу дослідити проблему естетичного виховання дітей в історичній ретроспективі; виявити соиіально-історичні передумови, що відображають еволючію теоретичних уявлень про сутність естетичного виховання й особливості його організаиії. Доведено, щяо на сучасному етапі необхідна побудова иілісної теорії естетичного виховання дітей, яка відображає досягнення сучасної педагогічної науки й забезпечує якісно нові можливості для створення і впровадження системи естетичного виховання підростаючого покоління в освітню практику.

Ключові слова: естетика; естетичне виховання; естетична культура; освітня практика.

Jim. 7.

Nelya Sirant, Assistant of the Elementary and Preschool Education Department Lviv Ivan Franko National University

\section{PROBLEMS OF AESTHETIC HEALTH OF CHILDREN IN HISTORICAL RETROSPECTIVES}

The article attempts to investigate the problem of aesthetic education of children in the historical retrospective; to identify the socio-historical background, reflecting the evolution of theoretical ideas about the essence of aesthetic education and the peculiarities of its organization. It is proved that at the present stage, the construction of a holistic theory of aesthetic education of children is necessary, which reflects the achievements of modern pedagogical science and provides qualitatively new opportunities for the creation and introduction of a system of aesthetic education of the young generation into educational practice.

The analysis of the concept "aesthetic education" is carried out, moreover, the research analyzes the main tendencies of its evolution, necessary for a more complete understanding of the problem of aesthetic education of children; in each historical period, the corresponding socio-historical background is identified.

It is proved that the basic provisions of aesthetic education are implemented in the kindergartens and schools by means of literature, music, fine arts, theater, cinema, architecture, dance, etc. In the last decade, the development of the problem of aesthetic education of children received a new impetus, and rethinking domestic and foreign pedagogical experience, the development of innovative processes served as the basis for a comprehensive study of the problem of aesthetic education of children, taking into account modern trends in the development of society and pedagogical science.

It is proved that a holistic theory of aesthetic education of children is necessary, based on the achievements of modern pedagogical science, which arranges the researcher to be an effective practical apparatus, which provides qualitatively new possibilities for the creation and introduction of the system of aesthetic education in a broad 


\section{ПРОБЛЕМИЕСТЕТИЧНОГО ВИХОВАННЯДІТЕЙ В ІСТОРИЧНІЙ РЕТРОСПЕКТИВІ}

educational practice. It is necessary to search for a new, perfect model of aesthetic education that reflects the state of modern society, education and art.

Keywords: aesthetics; aesthetic education; aesthetic culture; an educational practice.

П остановка проблеми. Кардинальні трансформації в соціокультурній сфері вимагають орієнтації на естетичне освоєння дитиною навколишньої дійсності як підгрунтя успішної соціалізації в сучасному суспільстві, що дозволяє їй осягнути все розмаїття духовного і матеріального світу та визначити власне місце у ньому. Притаманне будь-якій дитині естетичне начало, як головний елемент культури, $є$ загальною універсальною властивістю індивіда, оскільки містить прихований потенціал для виховання і становлення різнобічно розвиненої особистості.

На жаль, система освіти приділяє недостатню увагу належному розвитку особистості підростаючого покоління, здатного до естетичної трансформації навколишньої дійсності, визначаючи при цьому, як домінантний, спосіб орієнтування на практичну значущість (корисність), а не на еталон краси, прагнення до естетичної досконалості.

Позитивний потенціал для становлення i розвитку соціально зрілої, духовно багатої, високоморальної особистості накопичений вітчизняною системою естетичного виховання. Водночас слід наголосити, що її подальший розвиток має стати одним із пріоритетів державної політики в галузі освіти. Важливість і всеосяжний характер завдань, що виникають перед естетичним вихованням, підкреслюється у Національній стратегії розвитку освіти в Україні на період до 2021 року, де серед пріоритетних завдань освітньої галузі на сучасному етапі $\epsilon$ забезпечення естетичного розвитку особистості, формування естетичних цінностей, починаючи 3 ранньої родинної освіти [4].

Особливої актуальності естетичне виховання молодого покоління набуває на початковому етапі дитинства, оскільки саме в цей період найбільш інтенсивно формується естетичне ставлення до навколишнього світу, яке поступово трансформується в естетичні властивості особистості, передовсім в естетичний смак.

Аналіз останніх досліджень і публікацій. Значний вклад у дослідження проблеми естетичного виховання дітей внесли такі науковці, як І. Зязюн, М. Каган, В. Кудін, Б. Неменський, В. Сухомлинський та ін. У наукових дослідженнях зарубіжних і вітчизняних учених знайшли відображення різні аспекти естетичного виховання особистості, зокрема теоретико-методичні засади естетичного розвитку дітей (В. Рагозіна), розвиток естетичних смаків (Л. Гончаренко, Н. Калашник, В. Радкіна, І. Савчук) та естетичних цінностей (Л. Глазунова, О. Прокопова), особливості естетичного розвитку особистості засобами декоративно-ужиткового мистецтва (Д. Гусєв, М. Зимомря, В. Титаренко), дизайну (Д. Рудаков), творчих проектів (Л. Семьонова), у процесі позакласної виховної роботи (І. Паласевич) та ін.

Мета статті - дослідити проблему естетичного виховання дітей в історичній ретроспективі; виявити соціально-історичні передумови, що відображають еволюцію теоретичних уявлень про сутність естетичного виховання та особливості його організації.

Основний матеріал дослідження. Останнім часом спостерігається підвищений інтерес науковців і практиків до дослідження проблеми естетичного виховання підростаючого покоління та його ролі в гармонійному розвитку особистості дитини. Вивчаючи питання про сутність естетичного виховання дітей, необхідно передовсім звернугися до історії розвитку цього феномену, виокремивши й схарактеризувавши основні еволюційні періоди.

В основу виділення історичних періодів становлення і розвитку естетичного виховання дітей покладено соціально-історичні передумови, що відображають еволюцію теоретичних уявлень про сутність естетичного виховання й особливості його організації, взаємовідносини з процесами соціально-економічних і політичних перетворень в суспільстві, своєрідність культурного надбання тощо.

Аналіз літературних джерел дозволив нам в історії розвитку проблеми естетичного виховання дітей умовно виокремити чотири основні періоди:

- периий період (XVIII cm. - кінець XIX cm.) - відсутність цілеспрямованих досліджень проблеми естетичного виховання дітей;

- другий період (перша половина XX cm.) початок теоретичного вивчення окремих елементів проблеми естетичного виховання дітей;

- третій період (друга половина XX cm.) відновлення і розширення теоретичних досліджень проблеми естетичного виховання дітей;

- четвертий період (початок XXI cm. - до теперішнього часу) - комплексне дослідження проблеми естетичного виховання дітей.

Сучасною педагогічною наукою проведено грунтовний аналіз поняття “естетичне виховання", тому у дослідженні проаналізовано лише основні тенденції його еволюції, необхідні для більш 
повного осмислення проблеми естетичного виховання дітей, а також у кожному історичному періоді виокремлено відповідні соціальноісторичні передумови.

У контексті дослідження, необхідно відзначити, що поняття “естетичне виховання” в сучасному його розумінні до XVIII ст. взагалі не існувало [7, 40]. Тому, починаючи 3 античності і включаючи епоху Просвітництва, естетичне виховання дітей розглядалося не стільки в межах розвитку їх здатності розуміти та відчувати “прекрасне”, скільки як процес виховання засобами мистецтва, що допомагає виробити громадянські почуття, відчуття порядку і пропорційності.

Давньогрецькі філософи (Піфагор, Демокрит, Сократ, Платон, Аристотель й ін.), відзначаючи важливість занять мистецтвом для розвитку особистості, вперше обгрунтували ідеал виховання людини, заснований на гармонійному поєднанні фізичних і духовних цінностей та мистецтва як засобу виховання $[1,35]$.

Особливе місце у становленні основних ідей естетичного виховання належить епосі Відродження, гуманістичні погляди якої відкрили шляхи розвитку особистості через осягнення краси та гармонії мистецтва, заклали основи художньої освіти й виховання. В освітніх трактатах епохи Відродження виховання мистецтвом тісно пов' язувалося з питаннями загального виховання і не відокремлювалося від фізичного, етичного, інтелектуального. Значний вклад у розвиток ідеї естетичного виховання дітей внесли видатні педагоги Я. Коменський [2; 3] та Й. Песталоцці [3], котрі феномен “естетичне” трактували як важливий чинник виховання і навчання дітей, особливо в оволодінні певним видом мистецтва.

Таким чином, до початку першого періоду мистецтво розглядалося як важливий і необхідний засіб виховання дитини. Спроби теоретично осмислити мистецтво як чинник розвитку особистості дитини згодом ініціювали як розвиток теорії естетичного виховання.

Перший період розвитку проблеми естетичного виховання дітей (XVIII ст. - кінець XIX ст.) пов'язується з усвідомленням особливої цінності мистецтва як естетичного об'єкта, що зумовлювалося соціально-культурними особливостями цього історичного періоду. У відповідь на безвихідь, монотонність людського буття, що насаджувалися капіталістичними способами виробництва $з$ кінця XVII ст., сфера “естетичного” стала розглядатися як єдине середовище, де людська діяльність набувала особливої свободи й ціннісно-спрямованої орієнтації.

У XVIII ст. О. Баумгартеном вперше введено у науковий обіг термін “естетика” (від грец. "естетікос" - той, щуо відноситься до почуттів), яким, на відміну від логіки (науки про раціональне пізнання), позначалося вчення про чуттєве пізнання, необхідне для осягнення i створення прекрасного, його вираження у творах мистецтва $[6,39]$.

Ідея "прекрасного" не лише визначає всю змістовну сутність і спрямованість класичної естетики, а й одночасно стає предметом естетичного пізнання та принципом його організації. Обгрунтування специфіки естетичного виховання перетворюється на важливий елемент теорії естетики (Г. Гегель, І. Кант, Ф. Шиллер). Першим теоретиком естетичного виховання можна вважати Ф. Шиллера, який виокремив його теорію з філософської естетики. Жоден із філософів до нього не надавав естетичному ставленню людини до мистецтва настільки важливу культурно-історичну роль. Програма естетичного виховання Ф. Шиллера втілилася в утопію “естетичної держави” і модель “естетичної людини”, засновану на глибокому переконанні, що краса та мистецтво стануть потужним засобом звільнення, різнобічного і гармонійного розвитку особистості.

Ідея взаємозв'язку естетичного виховання та розвитку особистості почала активно розвиватися у XVIII - XIX ст. в працях відомих філософів, педагогів, письменників (О. Бестужев, В. Бєлінський, Н. Добролюбов, Н. Чернишевський, В. Острогорський та ін.). У ХІХ ст. ідеї естетичного виховання дітей представлені у низці педагогічних концепцій (С. Русова, К. Ушинський та ін.). Однак на практиці цілеспрямоване естетичне виховання дітей здійснювалося лише в дворянських і заможних родинах. У масовій школі спеціально організоване естетичне виховання дітей не здійснювалося, тому учні, чиї батьки не належали до багатих станів, не отримували відповідного естетичного впливу 3 боку системи освіти. У церковно-парафіяльних школах, де більшість дітей отримували початкову освіту, практично не було вчителів з предметів естетичного циклу, оскільки в педагогічних і вчительських інститутах не здійснювалася цілеспрямована підготовка вчителів музики і малювання.

Наприкінці XIX ст. стала гостро відчуватися необхідність кардинальних змін в системі освіти. В опублікованих того часу матеріалах щодо реформування школи увага акцентувалася на низькій ефективності процесу естетичного виховання, недостатній кількості предметів естетичного циклу в програмах більшості шкіл. 
Зазначалося, що недостатній розвиток відчуття прекрасного та художніх смаків гальмує творчий розвиток особистості учнів.

Другий етап (перша половина ХХ сm.) - це етап створення системи масового естетичного виховання дітей. Якщо на попередньому етапі естетичне виховання було здебільшого прерогативою еліти і заможних людей, то 3 трансформацією усіх сфер суспільного й економічного життя основні виховні функції починає переймати на себе суспільство. Провідною тенденцією на цьому етапі стає ідея всеосяжності освіти.

3 проголошенням незалежної Української Народної республіки у 1917 році було створено Міністерство освіти, основне завдання якого полягало у побудові єдиної діяльної (трудової) школи, що мала носити національний характер і грунтуватися на теорії Г. Кершенштайнера (“Трудова школа").

У 1918 році департамент дошкільної та позашкільної освіти при Міністерстві очолила видатний український педагог і просвітитель С. Русова, яка одним із головних пріоритетів розвитку школи визначила естетичний напрям. Відтак, з перших кроків реформування шкільної системи освіти була означена спрямованість на естетичне виховання учнів. Відповідно, у навчальний план загальної школи вводилися предмети естетичного циклу, зокрема спів і музика, ліплення, малювання. На початку 20-х рр. $\mathrm{XX}$ ст. під керівництвом Г. Ващенка на Полтавщині (с. Білики Кобеляцького повіту) створюється навчальний заклад для підготовки вчительських кадрів, при якому організовується хор і драматичний гурток, а також великого значення надається трудовому навчанню i художньому вихованню майбутніх педагогів.

Проте, наприкінці 20-х рp. ХХ ст. в силу ідеологічних і політичних чинників загальноосвітня школа, що стала провідною ланкою в системі естетичного виховання в СРСР, відмовляється від проголошеної орієнтації на всебічний розвиток творчої особистості учнів у процесі естетичного виховання. Існуючі наукові теорії естетичного виховання піддаються нищівній критиці, оскільки не вписуються у жорсткі рамки класової ідеології, коли виховання уявлялося лише як цілеспрямований, ідеологізований процес впливу вихователя на вихованця з метою вироблення в ньому тих особистісних якостей, які відповідають установкам пануючої політичної системи.

У $30-\mathrm{x} \mathrm{pp.} \mathrm{ХХ} \mathrm{ст.} \mathrm{естетичне} \mathrm{виховання} \mathrm{починає}$ розглядатися здебільшого як виховний процес, покликаний сприяти формуванню почуттів, смаків, поглядів відповідно до комуністичного ідеалу прекрасного. Ця концепція естетичного виховання на перший план виводила не лише розвиток естетичного сприйняття, а й процес впливу 3 метою формування соціально прийнятного для тогочасного періоду ідеологічного стереотипу. Визначення мети естетичного виховання як виховання здатності цілеспрямовано сприймати, відчувати красу в навколишній дійсності та природі, суспільному житті та праці, у творах мистецтва, виховання потреби і здатності посильно брати участь в їі створенні відповідно до комуністичних ідеалів, надовго увійшло в вітчизняну педагогічну науку і практику. При цьому наукові дискусії велися лише 3 приводу засобів естетичного виховання. Так, низка відомих радянських учених-педагогів (П. Блонський, А. Луначарський та ін.) вважали, що процес залучення до прекрасного має бути відірваний від технічної індустріальної цивілізації та зосереджений на “чистому” мистецтві. Їхні опоненти (С. Шацький, А. Макаренко та ін.) розширювали категоріальні межі естетичного виховання, розглядаючи “прекрасне" в суспільному житті, природі, праці, людських стосунках.

У 30 - 50-х рр. ХХ ст. в радянській системі освіти поступово витіснялося все, що мало відношення до процесу розвитку особистості дитини. У 1935 р. в школі відбулося скорочення до мінімуму навчального часу на співи i малювання. 3 другої половини 30-х рр. і до середини 50-х pp. ХХ ст. в СРСР не було опубліковано жодної книги або статті з проблем естетики та теорії естетичного виховання.

Третій період (друга половина XX cm.) знаменується кардинальними змінами в системі шкільної освіти. Освітня реформа 1958 р., разом 3 цілою низкою прогресивних новацій, передбачала окреслення перспектив й визначала необхідність вдосконалення естетичного виховання учнів. Так, спеціальна постанова Бюро ЦК КПРС "Про стан і заходи поліпшення естетичного виховання учнів загальноосвітніх шкіл" передбачала вивчення й узагальнення вітчизняного та зарубіжного досвіду, організацію широкого експерименту з вивчення предметів художнього циклу. Головними завданнями естетичного виховання було визначено не лише формування естетичних почуттів і смаків, розвиток емоційної сфери особистості, вміння відчувати “прекрасне" в мистецтві, природі, суспільних відносинах, а й озброєння школярів широкими теоретичними знаннями і практичними вміннями у різних мистецьких галузях. 


\section{ПРОБЛЕМИЕСТЕТИЧНОГО ВИХОВАННЯ ДІТЕЙ В ІСТОРИЧНІЙ РЕТРОСПЕКТИВІ}

У 60-х роках XX ст. спостерігається посилення інтересу вчених до теорії естетики та естетичного виховання. Вперше при розробці теорії естетичного виховання теоретично обгрунтована необхідність розмежування художнього та естетичного виховання. При цьому мистецтво розглядалося як один 3 основних засобів естетичного та художнього виховання.

Основні положення естетичного виховання в дитячому садку та школі засобами літератури, музики, образотворчого мистецтва, театру і танцю були розкриті в книзі “Загальні питання естетичного виховання в школі”, що вийшла під редакцією В. Шацької (1955). У книзі дано визначення сутності, цілей, завдань, засобів і змісту естетичного виховання; охарактеризовано методи художньої освіти та виховання, організаційні форми роботи. Трохи пізніше були опубліковані методичні розробки та посібники: В. Бєлобородова "Розвиток музичного слуху учнів I класу” (1957), “Про дитячий голос" під редакцією Н. Орлової (1966), Ю. Рубіна “Драматичний гурток в школі. V-VI класи” (1956), Е. Конорова і В. Светинська “Танцювальні гуртки старших школярів" (1958), Г. Лабунська “До питання про методи навчання малюванню в початковій школі” (1953) та ін.

Великого значення проблемі формування у молоді естетичного світогляду надавав видатний український вчений-педагог В. Сухомлинський, який зазначав, що у серці дитини мають надійно закарбуватися найкращі народні традиції, пам’ять про своє історико-культурне надбання. У книзі “Естетичне виховання і культура почуттів" [5] педагог звертає увагу на необхідність

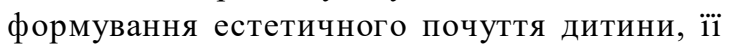
емоційної культури, що постає одним із головних завдань гуманістичної теорії виховання. Сприйняття й осмислення прекрасного, стверджував В. Сухомлинський, постає надійним підгрунтям естетичної культури, без якої почуття лишаються глухими до всього високого i благородного.

У 70-х рр. ХХ ст. розробляються нові програми 3 предметів естетичного циклу. Зокрема у початковій школі замість уроків малювання і співів з'являються предмети "Музика", “Образотворче мистецтво i художня праця”. Цей період становлення системи естетичного виховання знаменується створенням на базі педагогічних інститугів великої кількості музично-педагогічних і художньо-графічних факультетів, які здійснювали підготовку кваліфікованих кадрів для викладання дисциплін естетичного циклу в загальноосвітніх школах.
У 80-х рр. ХХ ст. знову актуалізувалася увага до проблем теорії і практики естетичного виховання як важливого засобу формування всебічно розвиненої, духовно багатої особистості. Ведеться активне дослідження мети, завдань, структури, рівнів естетичного виховання, а також мистецтва як основного засобу прилучення дітей до естетичної культури (М. Верб, С. Крупник, Л. Печко, Н. Киященко та ін.). У другій половині 80-х pp. ХХ ст. наукова, художня і педагогічна громадськість підійшла до усвідомлення необхідності реформування державної системи естетичного виховання, яка б орієнтувала заклади освіти на якісно новий рівень естетичного взаємодії дитини 3 навколишнім світом.

Четвертий період (початок XXI cm. - до теперішнього часу) пов'язаний з серйозними соціально-економічними трансформаціями в українському суспільстві, процесами демократизації та гуманізації в системі освіти, змінами ціннісних орієнтацій учнівської молоді. У суспільстві утверджується розуміння того, що саме через мистецтво здійснюється передача національнодуховного досвіду народу, відбувається встановлення і відновлення порушених зв'язків між поколіннями у справі естетичного виховання молоді.

Усвідомлення обмеженості раціонального пояснення світу, необхідність подолання погляду на людину лише як носія сукупності знань, умінь і навичок, зумовили інтерес до виявлення розвивальної функції мистецтва у становленні особистості дитини. Нарешті, зростаюче інтуїтивне розуміння того, що мистецтво найбільш ефективно допомагає дитині вибудовувати цілісну картину світу та приймати рішення в широкому спектрі життєвих ситуацій, призвело до орієнтації системи освіти на розвиток особистості школяра як суб'єкта єдиного культурного й освітнього простору, побудованого на основі діалогу культур.

В останнє десятиліття розвиток проблеми естетичного виховання дітей отримав новий імпульс. Переосмислення вітчизняного та зарубіжного педагогічного досвіду, розвиток інноваційних процесів послужили основою для комплексного вивчення проблеми естетичного виховання дітей з урахуванням сучасних тенденцій розвитку суспільства та педагогічної науки.

Вивчення різних аспектів естетичного виховання підростаючого покоління знайшло відображення у низці дисертаційних робіт вітчизняних учених: Л. Гончаренко (“Розвиток естетичних смаків майбутніх учителів засобами сучасної інструментальної музики”); Н. Калашник (“Історико-педагогічна генеза формування 


\section{ПРОБЛЕМИЕСТЕТИЧНОГО ВИХОВАННЯДІТЕЙ ВІСТОРИЧНІЙ РЕТРОСПЕКТИВІ}

естетичних смаків учнівської молоді у процесі навчально-виховної діяльності”); І. Паласевич (“Естетичне виховання підлітків у позакласній виховній роботі загальноосвітньої школи (друга половина XX ст.)”); С. Панасюк (“Формування культури побуту молодших школярів у системі естетичного виховання"); Н. Полтавської (“Формування духовних цінностей старшокласників засобами мистецтва”); В. Радкіна (“Формування художньо-естетичного смаку як професійної якості майбутнього вчителя”); І. Савчук (“Формування естетичних смаків учнів 5-9 класів на уроках трудового навчання засобами декоративно-ужиткового мистецтва") та ін.

Слід зазначити, що багато дослідників прийшли до висновку про необхідність нового підходу до занять мистецтвом в школі, більш широкого використання його виховних можливостей в родинному колі. Зусилля сучасних ученихпедагогів зосереджені, 3 одного боку, на визначенні принципів і змісту естетичного виховання школярів засобами театру, мистецтва читання, кіно, телебачення, Інтернету тощо, а 3 іншого - на підготовку методичних матеріалів, узагальнень передового педагогічного досвіду.

Висновки. Аналіз сформованих соціальноісторичних передумов, наукової літератури, освітньої практики показав, що нині педагогічне співтовариство стоїть на порозі нового періоду в розвитку уявлень про естетичне виховання підростаючого покоління. Вчені поступово приходять до усвідомлення того, що в першу чергу необхідна цілісна теорія естетичного виховання дітей, побудована на основі досягнень сучасної педагогічної науки, яка “озброює” дослідника ефективним практичним апаратом, що забезпечує якісно нові можливості для створення й упровадження системи естетичного виховання в широку освітню практику.

\section{ЛІТЕРАТУРА}

1. Антонова А.В. Эстетическое воспитание как средство формирования свободной личности в истории философской и педагогической мысли / А.В. Антонова, Т.С. Комарова // Проблемы свободного воспитания и развития личности. М., 1997. - С. 33-39.

2. Коменский Я.А. Материнская школа / Я.А. Коменский. - М.: АРНО Сервис. - 1992. - 64 с.
3. Коменский Я.А. Педагогическое наследие / Я.А. Коменский, И.Г. Песталоцци, Ж.-Ж. Руссо. - М.: Педагогика, 1987. - 416 с.

4. Національна стратегія розвитку освіти в Україні на період до 2021 року. URL: http:// zakon4.rada.gov.ua/laws/show/344/2013/ print1472788 461667940

5. Сухомлинський В.О. Естетичне виховання і культура почуттів. Вибрані твори: в 5 т. Київ: Рад. школа, 1976. -Т.1. - С. 177-184.

6. Философский словарь / под ред. И.Т. Фролова. - 4-е изд. - М.: Политиздат, 1991. $-250 \mathrm{c}$.

7. Шульга Р.П. Искусство и ценностные ориентации личности / Р.П. Шульга. - Киев: Наук. думка, 1989. - 120 с.

\section{REFERENCES}

1. Antonova, A. V. \& Komarova, T. S. (1997). Esteticheskoe vospitanie kak sredstvo formirovaniya svobodnoy lichnosti $\mathrm{v}$ istorii filosofskoy $\mathrm{i}$ pedagogicheskoy mysli [Aesthetic education as a means of forming a free personality in the history of philosophical and pedagogical thought]. The problems of free education and personal development. Moscov, pp. 33-39. [in Russian].

2. Komenskiy, Ya. A. (1992). Materinskaya shkola [Maternal school]. Moscov. ARNO Servis, 64 p. [in Russian].

3. Komenskiy, Ya. A., Pestalotstsi, I. G. \& Russo, Zh.-Zh. (1987). Pedagogicheskoe nasledie [Pedagogical heritage]. Moscov: Pedagogika, 416 p. [in Russian].

4. Natsionalna stratehiia rozvytku osvity v Ukraini na period do 2021 roku [National Strategy for the Development of Education in Ukraine until 2021]. Available at: http://zakon4.rada.gov.ua/laws/show/ 344/2013/print1472788 461667940 [in Ukrainian].

5. Sukhomlynskyi, V.O. (1976). Estetychne vykhovannia i kultura pochuttiv. Vybrani tvory: v 5 t. [Aeducation and a culture of feelings. Selected Works: in 5th v.]. Kyiv: Rad. shkola, Vol.1, pp. $177-$ 184. [in Ukrainian].

6. Frolova, I. T. (Ed.). (1991). Filosofskiy slovar [Philosophical Dictionary]. The 4th ed. Moscov: Politizdat, 250 p. [in Russian].

7. Shulga, R. P. (1989). Iskusstvo i tsennostnye orientatsii lichnosti [Art and personal value orientations]. Kyiv: Nauk. dumka, 120 p.[in Russian].

Стаття надійшла до редакції 10.12.2018

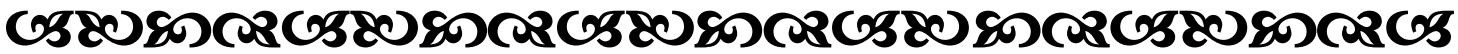

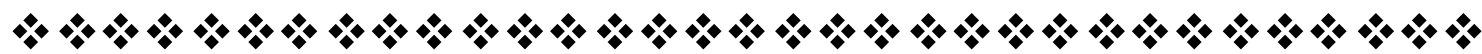

